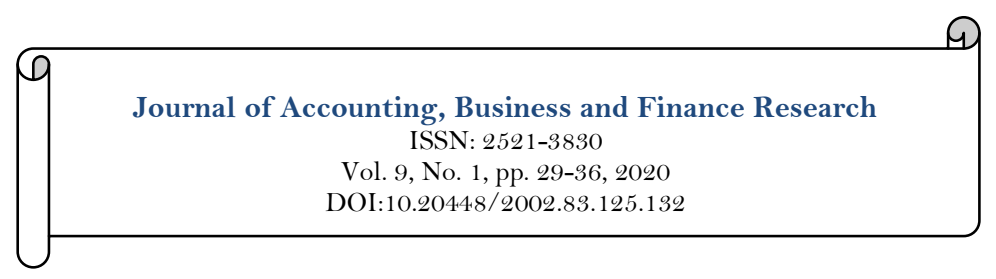

\title{
Mortgage, Treasury, CD and Fed Funds Rates Spreads and Risk Premiums: How do They Impact Net Interest Margins?
}

\author{
Mark Schaub ${ }^{1 *}$ \\ David R. Kaiser ${ }^{2}$
}

'Professor of Finance Department of Economics and Finance, SFA Station, Stephen F. Austin State University Nacogdoches, USA. Email:schaubm@sfasu.edu

'Chadwick Family Banking Program, Director Department of Economics and Finance SFA Station Stephen F. Austin State University, Nacogdoches, USA.

\section{Abstract}

This paper utilized FRED (Federal Reserve Economic Data) data from the Federal Reserve Bank of St. Louis to examine historical risk premiums between 30-year mortgages and 30-year T-Bonds and spreads between yields on these two assets and funding costs represented by 6-month CD rates and fed funds rates. Risk premiums were greatest and spreads were smallest (some-times negative) during the high interest rate environment during the late 1970's and early 1980's. Risk premiums got smaller after the two financial crises of the 2000's (the September 11, 2001 attack and the 2008 mortgage crisis) and the spreads became larger after both when the Federal Reserve cut rates tremendously. Despite these variations in income/cost spreads, net interest margins (to both total assets and earning assets) remained relatively stable. Regression analysis shows the best predictor of historical net interest margins was the 30-year treasury yield in lagged and non-lagged models. These results suggest the ability of banks to choose fund sources and fund uses allows them to reduce variation in net interest margins even while interest rates are volatile.
Keywords:

Bank management

Asset risk premiums

Asset/liability management

Mortgage rates

Treasury yields.

JEL Classification:

G20; G21; G29.

Licensed:

This work is licensed under a

Creative Commons Attribution 4.0

License.

Publisher:

Scientific Publishing Institute

Received: 12 February 2020

Revised: 16 March 2020

Accepted: 26 March 2020

Published: 7 April 2020

Funding: This study received no specific financial support.

Competing Interests: The authors declare that they have no competing interests.

\section{Introduction}

Banks rent money from customers and investors at one rate and rent the money back out to customers at a higher rate. Because the difference between interest income and interest costs (called the spread) is of vital importance to a bank's ability to cover non-interest expense and be profitable, special attention must be paid to rates on fund sources and fund uses. This paper utilizes FRED (Federal Reserve Economic Data) rates reported in past $\mathrm{H} .15$ releases of select interest rates to determine the challenge banks have had for the last 40 years in locking into profitable spreads in an operating environment with tremendous long-term and sometimes short-term volatility in interest rates.

Following the introduction, background information on the importance of rates in banking is given along with a short review of literature. Then, the sources of data and methods used to compute risk premiums and spreads are presented in the next section. A series of tables and figures show the historical rates of mortgages and treasuries, certificates of deposit (CDs) and federal funds rates and rate spreads in the results section. Also 
included are historical net interest margins and regressions to determine the best predictor of net interest margins. Finally, the paper is concluded.

\section{Background Information}

The main source of income for a bank traditionally has been the net interest income. This is the total interest received on loans, securities and other interest earning assets minus the interest paid on deposits, fed funds, discount loans and other sources of funds with an interest cost.

Banks often seek to offset some of the operating expenses with other non-interest sources of income (such as fee income, loan servicing income, trust income, etc.). The amount by which the non-interest expenses of the bank exceed the non-interest income, called the burden, must be covered by the net interest income in order for the bank to be profitable. An additional set-aside to cover loan defaults (called the provision for loan losses) is subtracted before determining the bank's pre-tax operating income (POI) as shown in Equation 1.

POI = NII - Burden - PLL

In Equation 1 above, POI is the pre-tax operating income; NII is net interest income (interest income minus interest expense); the Burden is non-interest expense minus non-interest income; and the PLL (provision for loan losses) is based on the risk taken in the loan portfolio. Because the net interest income is the predominant source of income for the bank, the bank net interest management process is often referred to as asset/liability management.

Loans, securities and interest-bearing balances comprise the majority of the earning assets of the bank. The main sources of interest expense appear on the liability side of the bank as deposits, fed funds, discount loans, Federal Home Loan Bank borrowings, bank notes and other liabilities. Historically the assets on a bank's balance sheet had longer maturities than the liabilities. Therefore banks were said to be borrowing short (i.e. short-term) and lending long (i.e. long-term). This maturity mismatch between assets and liabilities tends to be the biggest cause of changing spreads between interest income and interest expenses, which impact the bank's net interest income.

While the net interest income on the income statement is reported in units of currency (for example, dollars in the United States), a common practice in banking is to divide every item by total assets for comparison purposes (this practice is called common sizing). The net interest income divided by assets provides a spread in percent terms called the net interest margin which shows the difference between the average interest rates received on earning assets and the rates paid on liabilities. In the United States, each bank submits quarterly financials to the regulating authorities which is then provided to the public in the Uniform Bank Performance Report (UBPR) on the ffiec.gov website containing the above mentioned information.

\section{Literature Review}

Factors impacting net interest margin at commercial banks, and industry efforts to manage the spread between asset yields and funding costs has been extensively covered. The factors impacting net interest margins are many and varied, Demirguc-Kunt and Huizinga (1999) examined bank level data across 80 countries and found that individual bank characteristics, taxation, regulation and macroeconomic conditions all have an impact upon net interest margin.

English (2002) presented that commercial banks in industrial countries have generally managed their exposure to the yield curve in ways that have limited the effects upon their net interest margins, and suggest that changes in interest rates seem unlikely to undermine the health of the banking sector through their effects on net interest income.

In the European Union, Maudos and De Guevara (2004) provide evidence that relaxing competition obstructions and allowing banks to grow larger reduced bank risk and therefore net interest margins. A similar size-related NIM decreasing effect in the United States, resulting from deregulation in the 1990's, is found by DePrince and Morris (2007).Memmel and Schertler (2013) noted that changes in market-wide bank rates have a much higher explanatory power for net interest margins than changes in balance-sheet composition and attributed this to the use of interest rate derivatives by bankers to manage on-balance sheet risk. The impact of non-yield curve related influences on net interest margin has also been examined. Zarruk and Madura (2009) studied the impact of increases in capital requirements or deposit insurance premiums on net interest margin and found increases in those variables resulted in reduced net interest margin.

In examining determinants of net interest margin across developing and emerging economies (LopezEspinosa, Moreno, \& De Gracia, 2011) found that interest rate volatility is positively and strongly related to net interest margin dynamics in those environments.

These studies provide a basis for this one that examines the challenge banks have in maintaining profitable net interest margins in a volatile interest rate environment.

\section{Data Utilized and Methodology}

The data utilized to compute spreads was pulled from the Federal Reserve System FRED provided by the Federal Reserve Bank of St. Louis. These data include 30-Year Conventional Mortgage Rates (pulled 
February 26, 2019), 30-Year Treasury Constant Maturity Rates (pulled February 26, 2019), 6-Month Certificate of Deposit Secondary Market Rates (pulled February 26, 2019), Effective Federal Funds Rates (pulled March 3, 2019) and Quarterly Net Interest Margins based on average earning assets (pulled September 4, 2019). The data window starts in 1977, when 30-year treasury rates began being reported, and ends in December 2018. An exception is made for the 6-month CD rates, which was discontinued after June 2013. In addition, annual net interest margins (to total assets) were retrieved from the FDIC website for reporting purposes only (using annual rates in environments with substantial monthly and quarterly changes ignores the rate variability banks have to deal with in asset/liability management).

The two long-term assets (conventional mortgages and treasuries) represent different risk profile investment opportunities for banks. Bank regulatory requirements direct that banks must maintain minimum levels of capital in order to be considered well capitalized. One of the key calculations to determine capital adequacy is the calculation of Risk Based Capital. In the risk based capital calculation, assets are assigned weightings based on the inherit risk contained within the assets. Treasuries are assigned a $0 \%$ risk weight in the risk based capital calculation. Qualifying conventional mortgages (the FRED mortgage rates are for conventional loans of low risk) are assigned a 50\% risk-weighing due to their relatively higher risk, compared to a zero risk asset, while higher yielding mortgages (for example, subprime loans) are assigned a $100 \%$ risk weighting. A risk premium exists between the 30-year mortgage and the 30-year Treasury and is computed by subtracting the rate on the Treasury bond from the corresponding rate on the mortgage as shown below in Equation 2. The treasury historically has zero default risk, making it proxy as a risk-free asset. The risk premiums are computed each month starting in 1977 through the end of 2017.

Risk Premium $=$ Fixed Mortgage Rate - Treasury Bond Yield

The prevailing spreads between the asset returns (mortgages and treasuries) and two funding sources for which rates were available (6-month CDs and fed funds) are also computed each month to show how shortterm spreads between interest income and interest expenses change with market rates. The relevant spreads are computed as shown in Equation 3.

Spread $=\%$ rate on mortgage/treasury $-\%$ rate on CDs $/$ fed funds

The spread shows how much the percent return on the respective asset differs from that of the corresponding funding source. Large volatility and fluctuations in rates have resulted in times where the spread between the fund uses and the fund sources was negative. Rates, risk premiums, and spreads are reported monthly and quarterly. Net interest income data were only available for quarterly analysis.

In determining the best predictor(s) of net interest margins, partial and full regressions were estimated using net interest margin as the dependent variable and the 4 interest rate income/cost variables (30 year mortgage rates, 30 year treasury rates, 6 month certificate of deposit rates, Fed Funds rates) as independent variables as shown in Equation 4.

$\mathrm{NIMi}=\mathrm{a}+\mathrm{b} 1 \times 30$ YRMORT + b2 $\times$ 30YRTREAS + b3 x 6MOCDs + b4 x FEDFUNDS + e (4) where:

NIM is the quarterly net interest margin at time i;

3ORRMORT is the prevailing 30 year mortgage rate at time i;

30 TRTREAS is the prevailing 30 year treasury rate at time $\mathrm{i}$;

$6 M O C D s$ is the prevailing 6 month $\mathrm{CD}$ rate at time $\mathrm{i}$; and

FEDFUNDS is the prevailing Fed Funds rate at time i.

\section{Results}

Tables 1 through 3 and Figures 1 through 5 illustrate how risk premiums and spreads have changed over time. Figure 1 shows the monthly mortgage rates minus the monthly T-Bond rates from 1997 through 2018. The difference between the two rates (the risk premium) is the extra return a lender received for taking the default risk of the loan as opposed to investing in treasury securities (T-Bonds are expected to have no default risk). The corresponding Table 1 reports the highest (Hi), lowest (Lo) and average (Avg) values for the mortgages, treasuries and risk premiums broken down by decades.

Table-1. Historical risk premiums of 30-year mortgages versus 30-year treasury bonds ${ }^{1}$

\begin{tabular}{|c|c|c|c|c|c|c|c|c|c|}
\hline \multirow[t]{2}{*}{ Year } & \multicolumn{3}{|c|}{ 30-Year Mort rate } & \multicolumn{3}{|c|}{ 30-Year Treas Rate } & \multicolumn{3}{|c|}{ Risk Premium } \\
\hline & $\mathrm{Hi}$ & Lo & Avg & $\mathrm{Hi}$ & Lo & Avg & $\mathbf{H i}$ & Lo & Avg \\
\hline $1977-80$ & $12.9 \%$ & $8.7 \%$ & $9.9 \%$ & $10.3 \%$ & $7.6 \%$ & $8.5 \%$ & $2.8 \%$ & $0.8 \%$ & $1.4 \%$ \\
\hline 1980’s & $18.5 \%$ & $9.0 \%$ & $12.7 \%$ & $14.7 \%$ & $7.3 \%$ & $10.6 \%$ & $4.9 \%$ & $0.5 \%$ & $2.1 \%$ \\
\hline 1990’s & $10.5 \%$ & $6.7 \%$ & $8.1 \%$ & $9.0 \%$ & $5.0 \%$ & $7.0 \%$ & $1.9 \%$ & $0.5 \%$ & $1.1 \%$ \\
\hline 2000's & $8.5 \%$ & $4.8 \%$ & $6.3 \%$ & $6.6 \%$ & $2.9 \%$ & $4.9 \%$ & $2.5 \%$ & $0.2 \%$ & $1.4 \%$ \\
\hline 2010 's & $5.1 \%$ & $3.4 \%$ & $4.1 \%$ & $4.7 \%$ & $2.2 \%$ & $3.3 \%$ & $1.7 \%$ & $0.1 \%$ & $0.9 \%$ \\
\hline Overall & $18.5 \%$ & $3.4 \%$ & $8.0 \%$ & $14.7 \%$ & $2.2 \%$ & $6.7 \%$ & $4.9 \%$ & $0.1 \%$ & $1.4 \%$ \\
\hline
\end{tabular}

The risk premium is computed using Equation 2 in the text. 
In the late 1970's and early 1980's, uncharacteristically high rates resulted as double-digit inflation wreaked havoc on the economy. During those years the risk premiums of mortgages over treasuries were highest. This may be due to the unsustainability of these premiums from mortgage prepayment risk when rates went down (the risk homeowners would refinance the mortgage at new lower rates). Also, even though 30-year T-Bonds issued before 1985 were callable, they could not be called before 5 years prior to maturity.

In Table 2 and Figure 2 and 3, the spreads between 30-year mortgage rates and CD and fed funds rates are shown. Because banks tend to lend long-term (to a certain extent) while borrowing short-term, during times of high inflation fund sources (CDs and fed funds) can cost more than the return on the fund uses (mortgages and treasury securities). In Figure 2, the monthly spreads show for a brief time in the late 1970's and early 1980's, 6-month CDs cost more than the mortgage rates (making the spread negative). Also interesting from Figure 2 is how the CD rates went very low during the recovery periods from the stock market corrections after the September 11, 2001 terrorist attack and the 2008 mortgage crisis. While the stock market was down there was perhaps a "flight to quality" by investors who took their money out of declining equities and put it into insured deposits.

Table-2. Historical monthly spreads of 30-year mortgages versus 6-month CD and fed funds Rates ${ }^{2}$

\begin{tabular}{|c|c|c|c|c|c|c|c|c|c|}
\hline \multirow[t]{2}{*}{ Year } & \multicolumn{3}{|c|}{ 30-Year Mort Rate } & \multicolumn{3}{|c|}{6 Month Cd Rate } & \multicolumn{3}{|c|}{ Spread } \\
\hline & $\mathrm{Hi}$ & Lo & Avg & $\mathrm{Hi}$ & Lo & Avg & Hi & Lo & Avg \\
\hline $1977-80$ & $12.9 \%$ & $8.7 \%$ & $9.9 \%$ & $14.0 \%$ & $5.1 \%$ & $8.8 \%$ & $3.7 \%$ & $-2.2 \%$ & $1.2 \%$ \\
\hline 1980’s & $18.5 \%$ & $9.0 \%$ & $12.7 \%$ & $18.0 \%$ & $5.7 \%$ & $10.0 \%$ & $5.2 \%$ & $-2.5 \%$ & $2.7 \%$ \\
\hline 1990’s & $10.5 \%$ & $6.7 \%$ & $8.1 \%$ & $8.6 \%$ & $3.2 \%$ & $5.4 \%$ & $4.8 \%$ & $1.3 \%$ & $2.7 \%$ \\
\hline 2000’s & $8.5 \%$ & $4.8 \%$ & $6.3 \%$ & $6.9 \%$ & $0.3 \%$ & $3.3 \%$ & $5.2 \%$ & $0.8 \%$ & $3.0 \%$ \\
\hline 2010’s* & $5.1 \%$ & $3.4 \%$ & $4.1 \%$ & $0.8 \%$ & $0.3 \%$ & $0.4 \%$ & $4.7 \%$ & $3.0 \%$ & $3.8 \%$ \\
\hline Overall & $18.5 \%$ & $3.4 \%$ & $8.0 \%$ & $18.0 \%$ & $0.3 \%$ & $5.9 \%$ & $5.2 \%$ & $-2.5 \%$ & $2.8 \%$ \\
\hline \multirow[t]{2}{*}{ YEAR } & \multicolumn{3}{|c|}{ 30-Year Mort rate } & \multicolumn{3}{|c|}{ Fed Funds rate } & \multicolumn{3}{|c|}{ Spread } \\
\hline & $\mathrm{Hi}$ & Lo & Avg & $\mathrm{Hi}$ & Lo & Avg & $\mathrm{Hi}$ & Lo & Avg \\
\hline $1977-80$ & $12.9 \%$ & $8.7 \%$ & $9.9 \%$ & $13.8 \%$ & $4.7 \%$ & $8.3 \%$ & $4.0 \%$ & $-2.1 \%$ & $1.6 \%$ \\
\hline 1980 's & $18.5 \%$ & $9.0 \%$ & $12.7 \%$ & $19.1 \%$ & $5.9 \%$ & $10.0 \%$ & $6.2 \%$ & $-4.2 \%$ & $2.7 \%$ \\
\hline 1990's & $10.5 \%$ & $6.7 \%$ & $8.1 \%$ & $8.3 \%$ & $2.9 \%$ & $5.2 \%$ & $5.3 \%$ & $1.2 \%$ & $3.0 \%$ \\
\hline 2000's & $8.5 \%$ & $4.8 \%$ & $6.3 \%$ & $6.5 \%$ & $0.1 \%$ & $3.0 \%$ & $5.7 \%$ & $0.9 \%$ & $3.3 \%$ \\
\hline 2010 's & $5.1 \%$ & $3.4 \%$ & $4.1 \%$ & $2.4 \%$ & $0.1 \%$ & $0.5 \%$ & $4.9 \%$ & $2.2 \%$ & $3.7 \%$ \\
\hline Overall & $18.5 \%$ & $3.4 \%$ & $8.0 \%$ & $19.1 \%$ & $0.1 \%$ & $5.0 \%$ & $6.2 \%$ & $-4.2 \%$ & $3.1 \%$ \\
\hline
\end{tabular}

Note: ${ }^{2}$ Rates shown are based on FRED monthly rates from 1977 through 2018 obtained from the Federal Reserve Bank of St. Louis website.

The spreads are computed using Equation 3 in the text. *FRED stopped reporting CD rates after June 2013.

Figure 3 shows a similar pattern with mortgage rates versus fed funds spreads. Because FRED data was discontinued for 6-month CD rates, only Figure 3 shows the resulting spread reductions when the Federal Reserve starting increasing interest rates in 2017. Table 2 shows the spread between mortgage and CD rates got as high as 5.2 percent and as low as -2.5 percent. Likewise the spread between mortgage and fed funds rates was as high as 6.2 percent and as low as -4.2 percent. Once again, these negative spreads illustrate the problems with financing long-term fixed rate assets with short-term variable funds.

Table-3. Historical monthly spreads of 30-year t-bonds versus 6-month CD and fed funds rates ${ }^{2}$.

\begin{tabular}{|c|c|c|c|c|c|c|c|c|c|}
\hline \multirow[t]{2}{*}{ Year } & \multicolumn{3}{|c|}{ 30-Year T-Bond Rate } & \multicolumn{3}{|c|}{6 Month Cd Rate } & \multicolumn{3}{|c|}{ Spread } \\
\hline & $\mathrm{Hi}$ & Lo & Avg & $\mathrm{Hi}$ & Lo & Avg & $\mathrm{Hi}$ & Lo & Avg \\
\hline $1977-80$ & $10.3 \%$ & $7.6 \%$ & $8.5 \%$ & $14.0 \%$ & $5.1 \%$ & $8.8 \%$ & $2.7 \%$ & $-4.0 \%$ & $-0.2 \%$ \\
\hline 1980’s & $14.7 \%$ & $7.3 \%$ & $10.6 \%$ & $18.0 \%$ & $5.7 \%$ & $10.0 \%$ & $3.0 \%$ & $-5.4 \%$ & $0.6 \%$ \\
\hline 1990’s & $9.0 \%$ & $5.0 \%$ & $7.0 \%$ & $8.6 \%$ & $3.2 \%$ & $5.4 \%$ & $4.3 \%$ & $-0.1 \%$ & $1.6 \%$ \\
\hline 2000's & $6.6 \%$ & $2.9 \%$ & $4.9 \%$ & $6.9 \%$ & $0.3 \%$ & $3.3 \%$ & $4.4 \%$ & $-1.0 \%$ & $1.6 \%$ \\
\hline 2010’s* & $4.7 \%$ & $2.2 \%$ & $3.3 \%$ & $0.8 \%$ & $0.3 \%$ & $0.4 \%$ & $4.3 \%$ & $2.1 \%$ & $3.2 \%$ \\
\hline Overall & $14.7 \%$ & $2.2 \%$ & $6.7 \%$ & $18.0 \%$ & $0.3 \%$ & $5.9 \%$ & $4.4 \%$ & $-5.4 \%$ & $1.3 \%$ \\
\hline \multirow[t]{2}{*}{ YEAR } & \multicolumn{3}{|c|}{ 30-Year T-Bond Rate } & \multicolumn{3}{|c|}{ Fed Funds rate } & \multicolumn{3}{|c|}{ Spread } \\
\hline & $\mathrm{Hi}$ & Lo & Avg & $\mathrm{Hi}$ & Lo & Avg & $\mathrm{Hi}$ & Lo & Avg \\
\hline $1977-80$ & $10.3 \%$ & $7.6 \%$ & $8.5 \%$ & $13.8 \%$ & $4.7 \%$ & $8.3 \%$ & $3.1 \%$ & $-3.9 \%$ & $0.2 \%$ \\
\hline 1980’s & $14.7 \%$ & $7.3 \%$ & $10.6 \%$ & $19.1 \%$ & $5.9 \%$ & $10.0 \%$ & $3.2 \%$ & $-6.9 \%$ & $0.6 \%$ \\
\hline 1990’s & $9.0 \%$ & $5.0 \%$ & $7.0 \%$ & $8.3 \%$ & $2.9 \%$ & $5.2 \%$ & $4.5 \%$ & $-0.3 \%$ & $1.9 \%$ \\
\hline 2000's & $6.6 \%$ & $2.9 \%$ & $4.9 \%$ & $6.5 \%$ & $0.1 \%$ & $3.0 \%$ & $4.4 \%$ & $-0.9 \%$ & $2.0 \%$ \\
\hline 2010’s & $4.7 \%$ & $2.2 \%$ & $3.3 \%$ & $2.4 \%$ & $0.1 \%$ & $0.5 \%$ & $4.5 \%$ & $0.6 \%$ & $2.8 \%$ \\
\hline Overall & $14.7 \%$ & $2.2 \%$ & $6.7 \%$ & $19.1 \%$ & $0.1 \%$ & $5.0 \%$ & $4.5 \%$ & $-6.9 \%$ & $1.7 \%$ \\
\hline
\end{tabular}

website. The spreads are computed using Equation 3 in the text. *FRED stopped reporting CD rates after June 2013. 
In Table 3 and Figures 4 and 5, the spreads between 30-year T-Bond rates and CD and fed funds rates are reported. Before commenting on T-Bond yields and spreads it should be noted that 30-year T-Bonds issued from 1973 until 1984 were callable. According to Crabbe (1991) the Treasury could redeem callable T-Bonds at their par value within 5 years of maturity as long as 4 months' notice was given to investors. The redemption would take place on one of the interest payment dates (these bonds paid semi-annual interest). Although the Treasury still has the ability to issue callable bonds, they have not done so after 1984 because those bonds tend to be less liquid and have to pay higher interest rates.

The maximum T-Bond yields occurred in September and October of 1981 when the yields hit 14.7 percent. CD rates and fed fund rates actually exceeded this yield by 2.5 percent and 1.2 percent respectively. The range of T-Bond yields was the greatest during the 1980 s decade with a high value of 14.7 percent and a low value of 7.3 percent. Even though the bonds were callable, compared to using 6-month CDs and fed funds as fund sources, the spreads were sometimes negative and large (-5.4 percent for CDs and up to -6.9 percent for fed funds). The best spreads for T-Bonds occurred after the mortgage crisis in the 2010's when the Federal Reserve drastically cut rates to near zero on many treasury securities. CD rates and fed funds rates followed suit creating an average spread between the 30-year T-Bond and CDs of 3.2 percent and 2.8 percent versus fed funds. Once again, CD rates were discontinued on the H.15 in June of 2013 so Figure 4 ends with low fund costs and high spreads. Looking, however, at the T-Bonds versus fed funds in Figure 5, in 2017 the Fed started hiking interest rates, resulting in increasing funding costs and spreads going back below 1 percent.

Table-4. Quarterly rates and spreads. ${ }^{3}$

\begin{tabular}{|c|c|c|c|c|c|c|}
\hline Variable (period) & $\begin{array}{c}\text { Number of } \\
\text { Quarters }\end{array}$ & Mean & Median & Std Dev & High & Low \\
\hline $\begin{array}{l}\text { 30-Yr Mortgage (1977- } \\
\text { 2018) }\end{array}$ & 168 & $8.03 \%$ & $7.38 \%$ & $3.41 \%$ & $18.45 \%$ & $3.38 \%$ \\
\hline $\begin{array}{l}\text { 30-Yr } \\
2018)\end{array}$ Treasury $\quad$ (1977- & 168 & $6.65 \%$ & $6.02 \%$ & $2.93 \%$ & $14.68 \%$ & $2.23 \%$ \\
\hline $\begin{array}{ll}\text { Risk Premium: Mort - } \\
\text { Treas }\end{array}$ & 168 & $1.38 \%$ & $1.28 \%$ & $0.71 \%$ & $4.93 \%$ & $0.22 \%$ \\
\hline $\begin{array}{l}\text { FRED } 6 \text { month CD rates } \\
(1977-6 / 2013)\end{array}$ & 146 & $5.86 \%$ & $5.61 \%$ & $3.86 \%$ & $17.4 \%$ & $0.26 \%$ \\
\hline $\begin{array}{l}30 \text { Yr Mortgage }-\mathrm{CD} \\
\text { rates spread }\end{array}$ & 146 & $2.77 \%$ & $3.06 \%$ & $1.44 \%$ & $5.15 \%$ & $-2.19 \%$ \\
\hline $\begin{array}{l}30 \text { Yr Treasury - CD rates } \\
\text { spread }\end{array}$ & 146 & $1.34 \%$ & $1.40 \%$ & $1.83 \%$ & $4.35 \%$ & $-4.40 \%$ \\
\hline $\begin{array}{l}\text { Fed Funds rates (1977- } \\
\text { 2018) }\end{array}$ & 168 & $4.99 \%$ & $5.14 \%$ & $4.14 \%$ & $19.08 \%$ & $0.07 \%$ \\
\hline $\begin{array}{l}30 \text { Yr Mortgage }- \text { Fed } \\
\text { Funds spread }\end{array}$ & 168 & $3.04 \%$ & $3.36 \%$ & $1.58 \%$ & $5.27 \%$ & $-4.18 \%$ \\
\hline $\begin{array}{l}30 \text { Yr Treasury }- \text { Fed } \\
\text { Funds spread }\end{array}$ & 168 & $1.65 \%$ & $1.87 \%$ & $1.95 \%$ & $4.49 \%$ & $-6.94 \%$ \\
\hline $\begin{array}{l}\text { FRED Quarterly NIM to } \\
\text { Earning Assets } \\
\text { (1984-2018) }\end{array}$ & 140 & $3.84 \%$ & $3.92 \%$ & $0.39 \%$ & $4.91 \% \%$ & $3.01 \%$ \\
\hline $\begin{array}{l}\text { FDIC Annual NIM to } \\
\text { Total Assets } \\
(1977-2017)\end{array}$ & 41 years & $3.16 \%$ & $3.16 \%$ & $0.31 \%$ & $3.81 \%$ & $2.60 \%$ \\
\hline
\end{tabular}

Source: ${ }^{3}$ Rates shown are based on FRED monthly rates from 1977 through 2018 obtained from the Federal Reserve Bank of St. Louis website. The spreads are computed using Equation 3 in the text. *FRED stopped reporting CD rates after June 2013. Annual FDIC year-end NIMs are also included.

In Table 4, the quarterly rates, risk premiums, spreads and net interest margins data are described with ranges (highs and lows), means, medians and standard deviations (Std Dev in the table). The data show large ranges of rates, spreads and risk premiums where data from the late 1970s and early 1980s were included. Unfortunately, the best net interest margin data (quarterly NIMs from FRED) only began in 1984 and excluded the most volatile interest rate periods. During the time frame for which the NIMs to earning assets from FRED are available, there is little volatility for the 35 year period. The annual FDIC year-end NIMs 
included (computed versus total assets) show little volatility as well but unfortunately excludes all of the interyear rate changes that occurred.

Table-5. Regressions with quarterly net interest margin as dependent variable ${ }^{1}$.

\begin{tabular}{|c|c|c|c|c|c|c|c|}
\hline Models & $\begin{array}{c}\text { 30-Yr } \\
\text { Mortgage }\end{array}$ & $\begin{array}{c}\text { 30-Yr } \\
\text { Treasury }\end{array}$ & $\begin{array}{c}\text { FRED } 6 \\
\text { month } \\
\text { CD } \\
\text { rates }\end{array}$ & $\begin{array}{c}\text { Fed } \\
\text { Funds } \\
\text { rates }\end{array}$ & Intercept & $\begin{array}{c}\text { R- } \\
\text { Squared }\end{array}$ & $\begin{array}{c}\text { F- } \\
\text { Value }\end{array}$ \\
\hline \multicolumn{8}{|c|}{ Panel 1. Quarterly NIM versus Independent Variables (not lagged) } \\
\hline Model $1(n=140)$ & $.0895^{* *}$ & & & & $3.20^{* *}$ & .3854 & $77.64^{* *}$ \\
\hline Model $2(\mathrm{n}=140)$ & & $.1049 * *$ & & & $3.22^{* *}$ & .4136 & $98.02^{* * *}$ \\
\hline Model $3(n=118)$ & & & $.0442^{* *}$ & & $3.73^{* *}$ & .1358 & $18.38 * *$ \\
\hline Model $4(n=140)$ & & & & $.0681 * *$ & $3.58^{* *}$ & .2728 & $52.15^{* * *}$ \\
\hline $\begin{array}{l}\text { Full Model }(\mathrm{n}= \\
118)\end{array}$ & $-.1847 * *$ & $.2628 * *$ & -.0669 & .0798 & $3.62^{* *}$ & .3280 & $13.91 * *$ \\
\hline
\end{tabular}

Panel 2. Quarterly NIM versus Independent Variables (lagged one quarter)

\begin{tabular}{l|l|l|l|l|l|l|l}
\hline Model 1 $(\mathrm{n}=139)$ & $.0901^{* *}$ & & & & $3.21^{* *}$ & .3521 & $75.01^{* *}$ \\
\hline Model 2 (n=139) & & $.1057^{* *}$ & & & $3.23^{* *}$ & .4065 & $94.51^{* *}$ \\
\hline Model 3 $(\mathrm{n}=117)$ & & & $.0452^{* *}$ & & $3.73^{* *}$ & .1408 & $19.00^{* *}$ \\
\hline Model 4 (n=139) & & & & $.0690^{* *}$ & $3.58^{* *}$ & .2752 & $52.39^{* *}$ \\
\hline $\begin{array}{l}\text { Full Model ( }= \\
117)\end{array}$ & $-.1882^{* *}$ & $.2572^{* *}$ & -.0478 & .0693 & $3.65^{* *}$ & .3099 & $12.68^{* *}$ \\
\hline
\end{tabular}

Note: ${ }^{1}$ In the first panel, quarterly net interest margins are regressed against the individual variables and all of them together as well. In the second panel, net interest margins are regressed against values of the individual variables for the previous quarter. *** denotes the item is significant at an alpha level of .01.

Table 5 shows the regression results using quarterly NIM as the dependent variable and the various asset and liability yields as the independent variables. In panel 1, the regressions show the impact of each single variable and of all of them together using end-of-quarter data for both the independent and dependent variables. In the individual models the income variables had better predictive abilities based on higher Rsquared values; however the cost variables did not predict NIM as well. Of the two interest income variables, treasuries predicted better while the Fed Funds rates were the better predictor of the interest expense variables. In the full model the interest income variables are both significant and the interest expense variables are both insignificant. All regressions including 6 month CD rates have less observations since FRED ceased including that data in the H.15 reports in 2013.

Panel 2 of Table 5 shows regression results when the NIMs are lagged. That means interest income and interest expense variables from the previous quarter were used to predict net interest margins for the next quarter. The predictive ability of each variable was about the same using the lagged models with the income variables predicting a little less based on R-squares and the cost variable predicting a little better. Once again the full model had the interest income variables as significant contributors and the interest expense variables as insignificant.

\section{Conclusion}

This paper examined historical risk premiums between 30-year mortgages and 30-year T-Bonds using FRED data to determine how rewards for taking the extra default risk of mortgages changed over time for the last 4 decades. Also included was a look at spreads between these two asset yields and fund costs represented by 6 -month $\mathrm{CD}$ rates and fed funds rates. Risk premiums were greatest during the high interest rate environment during the late 1970's and early 1980's perhaps because mortgage loans had much more prepayment risk (when rates have nowhere to go but down, customers are expected to refinance to get lower rates). Also, these periods accounted for negative spreads between fund uses (assets such as mortgage loans and T-Bonds) and fund sources (liabilities such as CDs and fed funds) because banks tend to lend long and borrow short. These same risk premiums got smaller and the spreads became larger after the mortgage crisis of 2008 when the Federal Reserve cut rates tremendously.

Overall, when examining the behaviour of risk premiums and income-cost spreads volatility and unpredictability occurred both during times of high interest rates and low interest rates.

One might think these unpredictable variations could potentially add risk to the banking system. However, in examining historical net interest margins, these were consistently positive with little variation. The ability of banks to reduce assets to the level of lower-cost deposits (both before and after the phase out of Regulation $Q$ in 1980) may have played an important role in keeping NIMs stable. Also it may explain why 
the interest income variables (mortgages and treasuries) had better predictive power of NIMs than interest expense variables (fed funds and CDs).

\section{References}

Crabbe, L. E. (1991). Callable corporate bonds: A vanishing breed. Financial and Economics Discussion Series 115, Board of Governors of the Federal Reserve System (U.S.), Revised 1991.

Demirguc-Kunt, A., \& Huizinga, H. (1999). Determinants of commercial bank interest margins and profitability: Some international evidence. The World Bank Economic Review, 13(2), 379-408.Available at: https://doi.org/10.1093/wber/13.2.379.

DePrince, A. E., \& Morris, P. D. (2007). A longitudinal study of net interest margin by bank asset size: 1992-2005. Journal of Economics and Finance, 31(1), 20-32.Available at: https://doi.org/10.1007/bfo2751509.

English, W. B. (2002). Interest rate risk and bank net interest margins. BIS Quarterly Reviere, 7(4), 67-82.

Lopez-Espinosa, G., Moreno, A., \& De Gracia, F. P. (2011). Banks' net interest margin in the 2000s: A macro-accounting international perspective. Journal of International Money and Finance, 30(6), 1214-1233.Available at: https://doi.org/10.1016/j.jimonfin.2011.06.001.

Maudos, J. n., \& De Guevara, J. F. (2004). Factors explaining the interest margin in the banking sectors of the European Union. Journal of Banking छ Finance, 28(9), 2259-2281.Available at: https://doi.org/10.1016/j.jbankfin.2003.09.004.

Memmel, C., \& Schertler, A. (2013). Bank management of the net interest margin: New measures. Financial Markets and Portfolio Management, 27(3), 275-297.Available at: https://doi.org/10.1007/s11408-013-0212-y.

Zarruk, E. R., \& Madura, J. (2009). Optimal bank interest margin under capital regulation and deposit insurance. Journal of Financial and Quantitative Analysis, 27(1), 143-149.Available at: https://doi.org/10.2307/2331303.

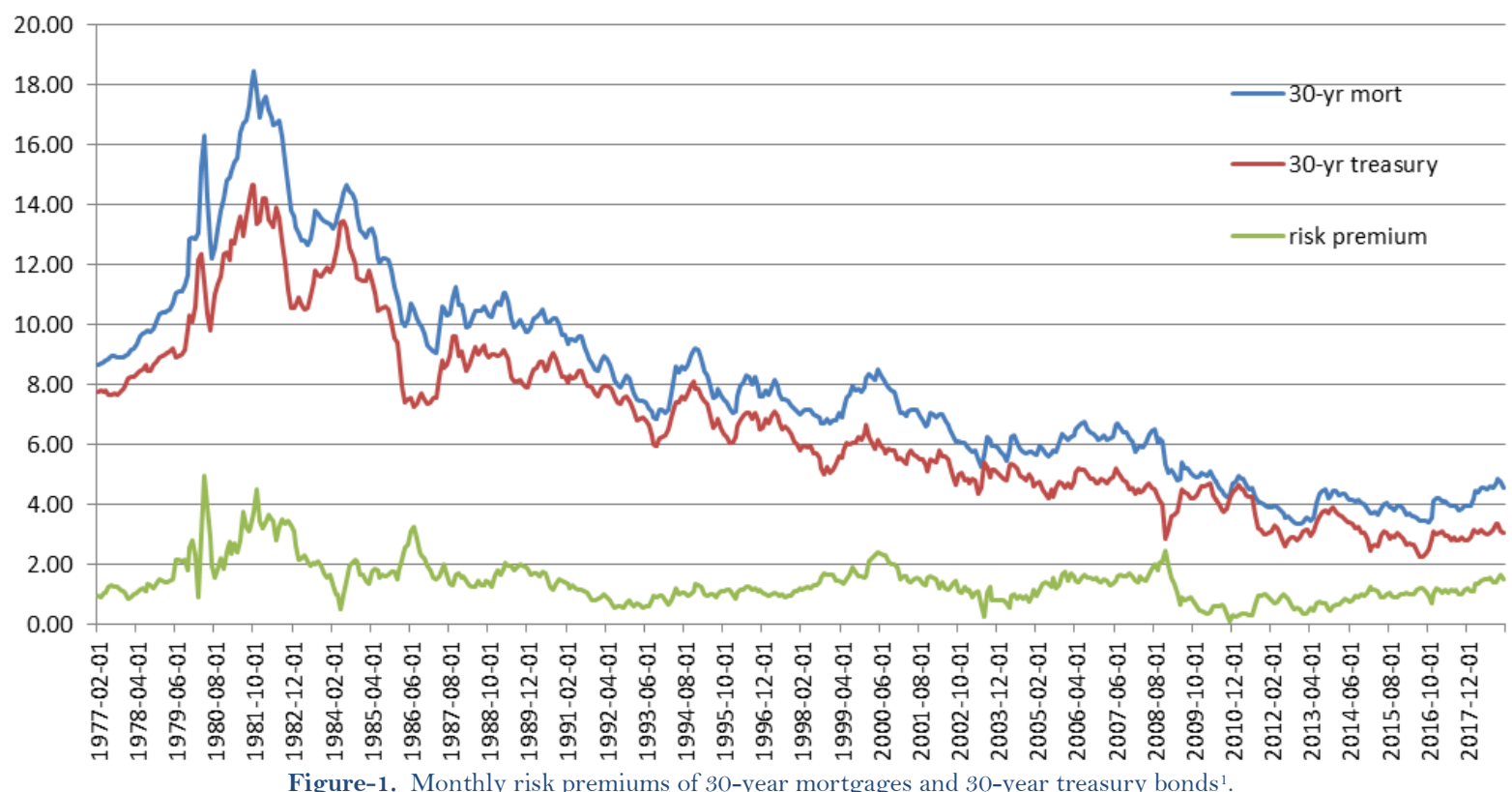

${ }^{1}$ Rates shown are based on FRED monthly rates from 1977 through 2018 obtained from the Federal Reserve Bank of St. Louis website. The risk premium is computed using Equation 2 in the text.

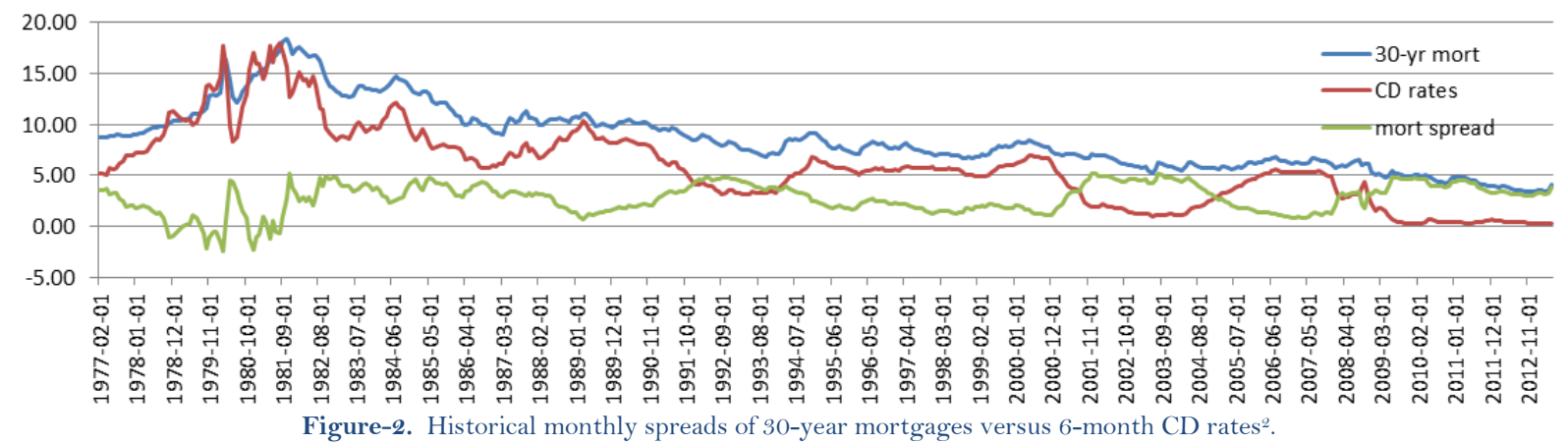

${ }^{2}$ Rates shown are based on FRED monthly rates from 1977 through 2018 obtained from the Federal Reserve Bank of St. Louis website. The spreads are computed using Equation 3 in the text. FRED stopped reporting CD rates after June 2013. 


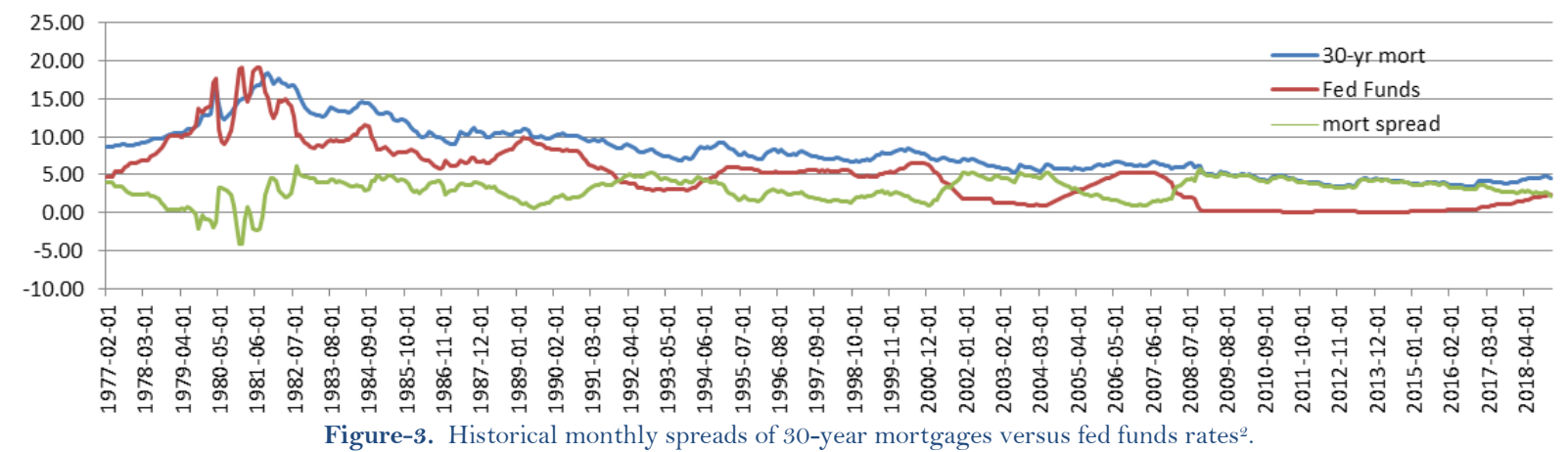

2Rates shown are based on FRED monthly rates from 1977 through 2018 obtained from the Federal Reserve Bank of St. Louis website. The spreads are computed using Equation 3 in the text.

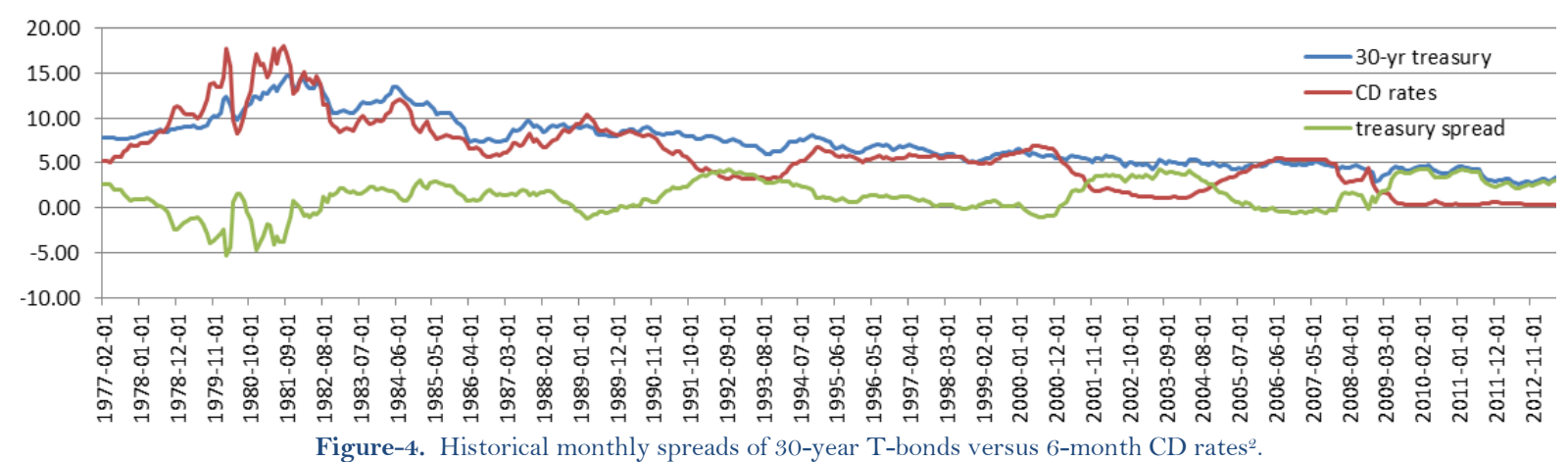

${ }^{2}$ Rates shown are based on FRED monthly rates from 1977 through 2018 obtained from the Federal Reserve Bank of St. Louis website. The spreads are computed using Equation 3 in the text. FRED stopped reporting CD rates after June 2013.

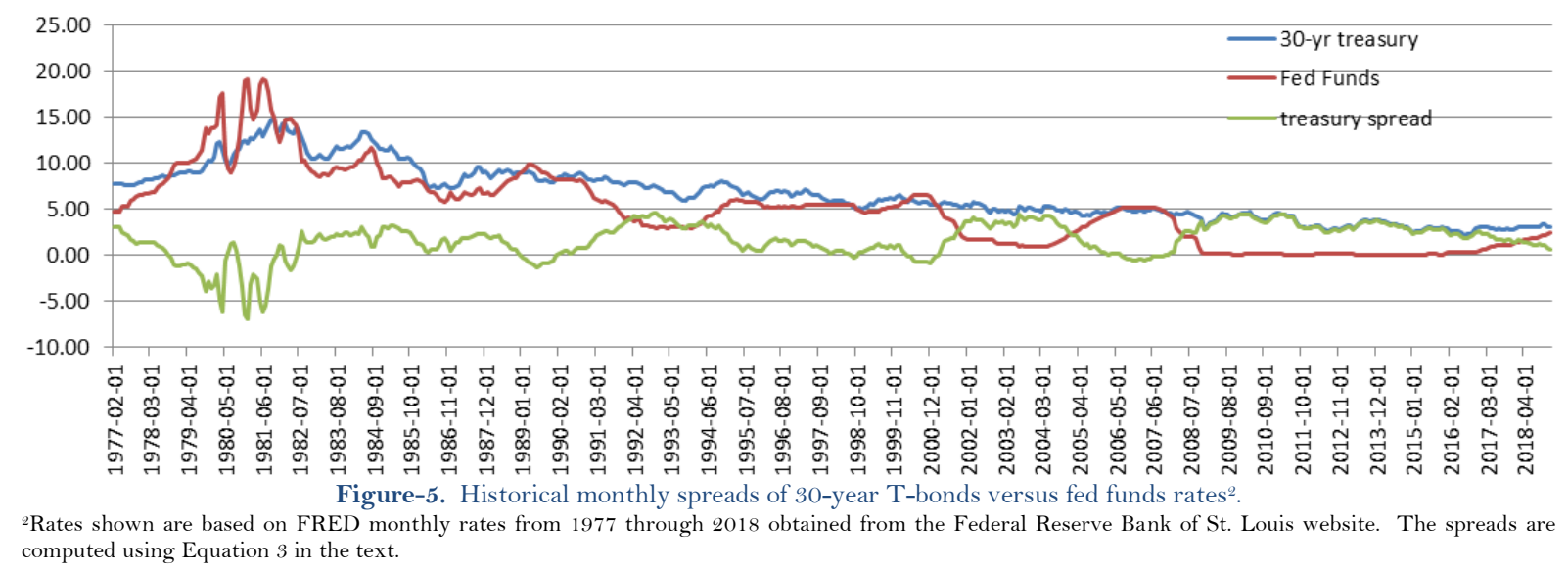

